\title{
Rilievo Urbano e City Information Modelling per la valutazione della vulnerabilità sismica
}

\author{
Federico Mario La Russa \\ Cettina Santagati
}

Abstract

L'articolo propone la definizione di una metodologia che integra i metodi consolidati del rilievo urbano all'attuale paradigma del City Information Modeling di supporto alla valutazione della vulnerabilità sismica a scala urbana adottando un approccio speditivo. Tale approccio si fonda sull'utilizzo del geo-dato (in genere in possesso delle pubbliche amministrazioni o disponibile in open-data) quale fonte indiretta attraverso cui strutturare il modello di città informato e responsivo. Inoltre, viene introdotta una strategia di modellazione procedurale basata sulla conoscenza dei tipi edilizi per integrare le informazioni di base e ottenere valutazioni di massima iniziali. Tale approccio garantisce la sostenibilità economica dell'intervento iniziale, rimandando a tempi successivi le operazioni di rilievo digitale necessarie per una conoscenza e descrizione geometrica accurata delle unità edilizie, ma onerose sia in termini di costi che di energie.

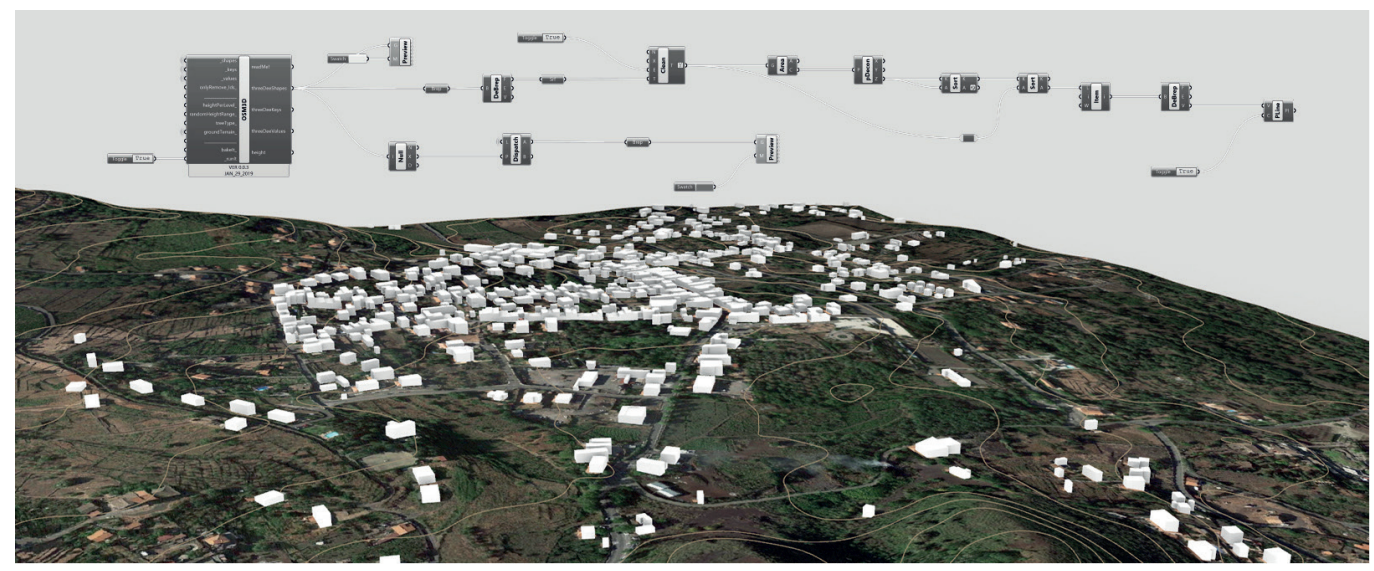




\section{Introduzione}

L'alta sismicità del territorio italiano rende fragile il patrimonio costruito delle nostre città. Conoscerne i diversi gradi di vulnerabilità sismica, e pertanto del rischio ad essa connesso, consente di stabilire le priorità di intervento in modo da ottimizzare le risorse finanziarie da investire. Se il percorso di conoscenza indicato dalle Linee Guida del 20 I I (LLGG 20 I I) permette di definire un iter per i singoli manufatti architettonici, la sua estensione alla scala della città e degli aggregati urbani richiede che l'indagine conoscitiva tenga conto della complessità e della multidimensionalità dei diversi aspetti che caratterizzano la città e la struttura urbana, all'interno della quale ogni singola unità oltre ad essere connotata dalla sua specificità è interrelata con gli edifici circostanti. Le consolidate metodologie del Rilievo Urbano [Baculo 1994; Vernizzi 2006; Caniggia 2008; Garzino 2019; Boido 2021] che descrivono e rappresentano "l'insieme dei valori presenti nelle realtà indagate, al fine di costruire l'insieme di invarianti formali e strutturali" [Coppo 2010, p. 12], risultano ancora oggi di grande attualità (fig. I) e forniscono il substrato teorico alle sperimentazioni legate all'applicazione del paradigma del City Information Modelling per lo sviluppo di modelli di città informati e responsivi per la valutazione della vulnerabilità sismica.

Attribuire una definizione univocamente riconosciuta al City Information Modeling è un tema attuale nel dibattito internazionale, considerata la natura ibrida tra ambiente BIM e GIS. È possibile identificare dei caratteri specifici che permettono di distinguere in maniera netta un CIM da un GIS 3D o un BIM esteso alla scala urbana. In accordo con Xue [Xue et al. 202 l], la discriminante utile per questa operazione sta nel significato che la 'l' di 'Information' assume nel CIM rispetto a GIS e BIM.

I primi sviluppi del CIM possono essere individuati nelle applicazioni volte alla connessione tra nuvole di punti ottenute mediante rilievi strumentali (laser scanning, fotogrammetria) e modelli 3D geo-riferiti ottenuti in ambiente GIS [Julin 20I8] (fig. 2). In questi modelli l'informazione veniva (e viene ancora) stratificata per layer all'interno di geometrie mono/ bidimensionali [Goodchild 199I; Lu 2018]. A differenza del GIS, il CIM tiene conto anche di informazioni (come analisi dei flussi urbani, simulazioni energetiche, tecniche costruttive, etc.) che stanno in relazione tra loro attraverso rapporti di causa-effetto (similmente a quanto accade nel BIM) e non soltanto per adiacenza topologica. È possibile comunque affermare che un modello 3D semanticamente definito all'interno di un ambiente GIS può essere considerato una specifica tipologia di CIM [Xu 2014; Liu 2017].

Fig. I. Rilievo del quartiere di via Pietro Micca (Torino) e analisi dell'edificato secondo [Coppo 2010].
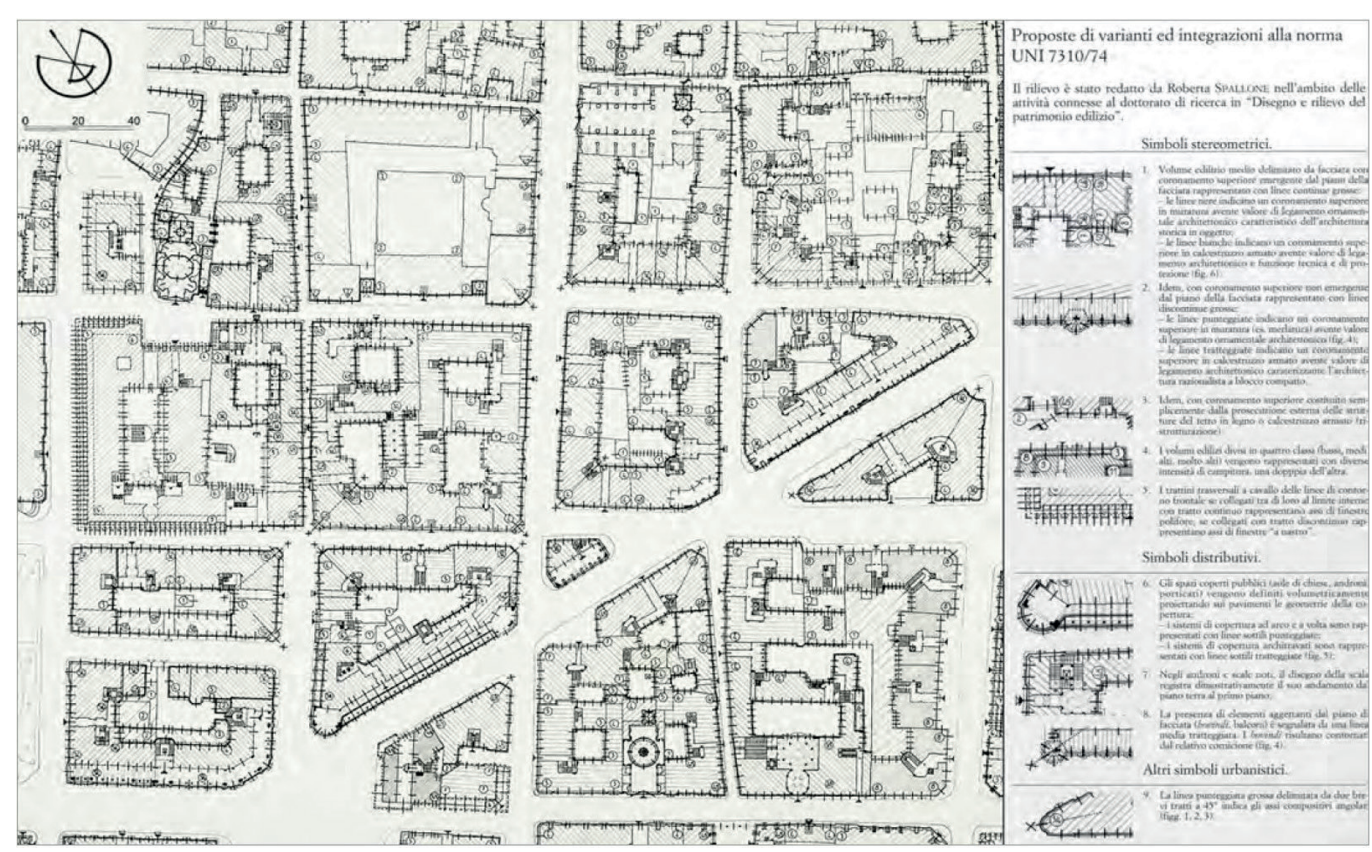


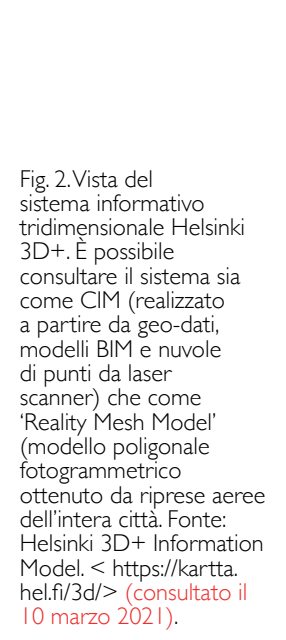

Helsinki

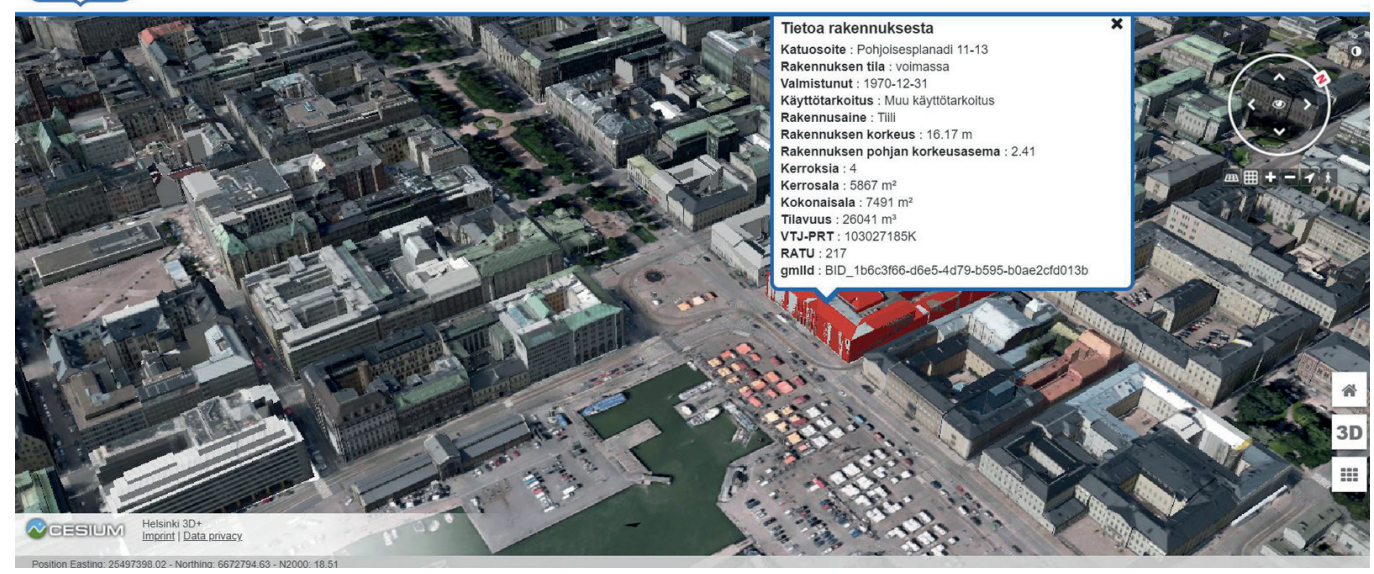

Se il BIM riguarda tutte le informazioni alla scala architettonica funzionali alla progettazione, gestione e conservazione di una data architettura, nel CIM interviene la relazione tra la singola unità architettonica e le informazioni legate al contesto urbano tridimensionale [Xu 2014$].$ La ricerca qui presentata ha come obiettivo principale la definizione di una metodologia che integra i metodi consolidati del rilievo urbano per lo sviluppo di un CIM di supporto alla valutazione della vulnerabilità sismica adottando un approccio speditivo.

In questa direzione si individuano due ulteriori sotto obiettivi: la definizione di un flusso di lavoro per l'analisi della vulnerabilità sismica di tipo deterministico; la messa a punto di un metodo di modellazione procedurale basato sulla conoscenza dei tipi edilizi per ottenere valutazioni di massima iniziali.

\section{Una metodologia innovativa per la modellazione degli aggregati urbani}

Nel panorama italiano si riscontrano esperienze condotte da diversi gruppi di ricerca sul tema del rilievo e rappresentazione della città attraverso sistemi informativi 2D/3D finalizzati alla prevenzione e gestione del rischio sismico quali ad esempio la metodologia ARIM (Assessment Reconstruction Information Modelling) sviluppata in occasione del terremoto di Amatrice [Empler 20 I9] (fig. 3), l' HT_BIM (Historical Town Building Information Modelling) per l'analisi del rischio nei centri storici [Pelliccio et al. 20 I7] (fig. 4), il progetto "La vulnerabilità sismica degli edifici storici in aggregato. Nuove metodologie e approcci speditivi e di modellazione strutturale" [Greco, Lombardo 20 I8] hanno fornito il background di riferimento metodologico per la ricerca condotta (fig. 5).

La metodologia proposta in questa sede se ne discosta poiché è finalizzata a conseguire una maggiore integrazione e dialogo tra le due discipline maggiormente interessate: il rilievo e la modellazione urbana da una parte e la scienza delle costruzioni dall'altra.

La ricerca prevede l'utilizzo di dati diretti (rilievi in sito) e derivati (Geo-Dati presenti sul territorio) per la realizzazione di un City Information Model di supporto alla valutazione sismica su scala urbana. La metodologia si compone di un framework principale che partendo da geo-dati integrati con il rilievo urbano, dallo studio dei tipi edilizi e dalla modellazione procedurale arriva a definire un CIM che contiene tutte le unità edilizie dell'area territoriale considerata. Per quanto l'approccio parametrico si coniughi bene con lo studio delle tipologie e risponda alle necessità di creare modelli analitici utili per l'analisi della vulnerabilità sismica delle unità edilizie in aggregati urbani, tuttavia in presenza di emergenze architettoniche sarà necessario un approfondimento che tenga conto delle peculiarità e unicità.

La modellazione del CIM avviene in maniera semi-automatica sfruttando le potenzialità dei linguaggi di programmazione visuale (VPL) che permettono, all'interno di specifici ambienti di modellazione digitale, una gestione delle geometrie parametrica e responsiva. 
Fig. 3. Ambienti di modellazione della procedura ARIM: dal modello parametrico a modello BIM [Calvano 2019].
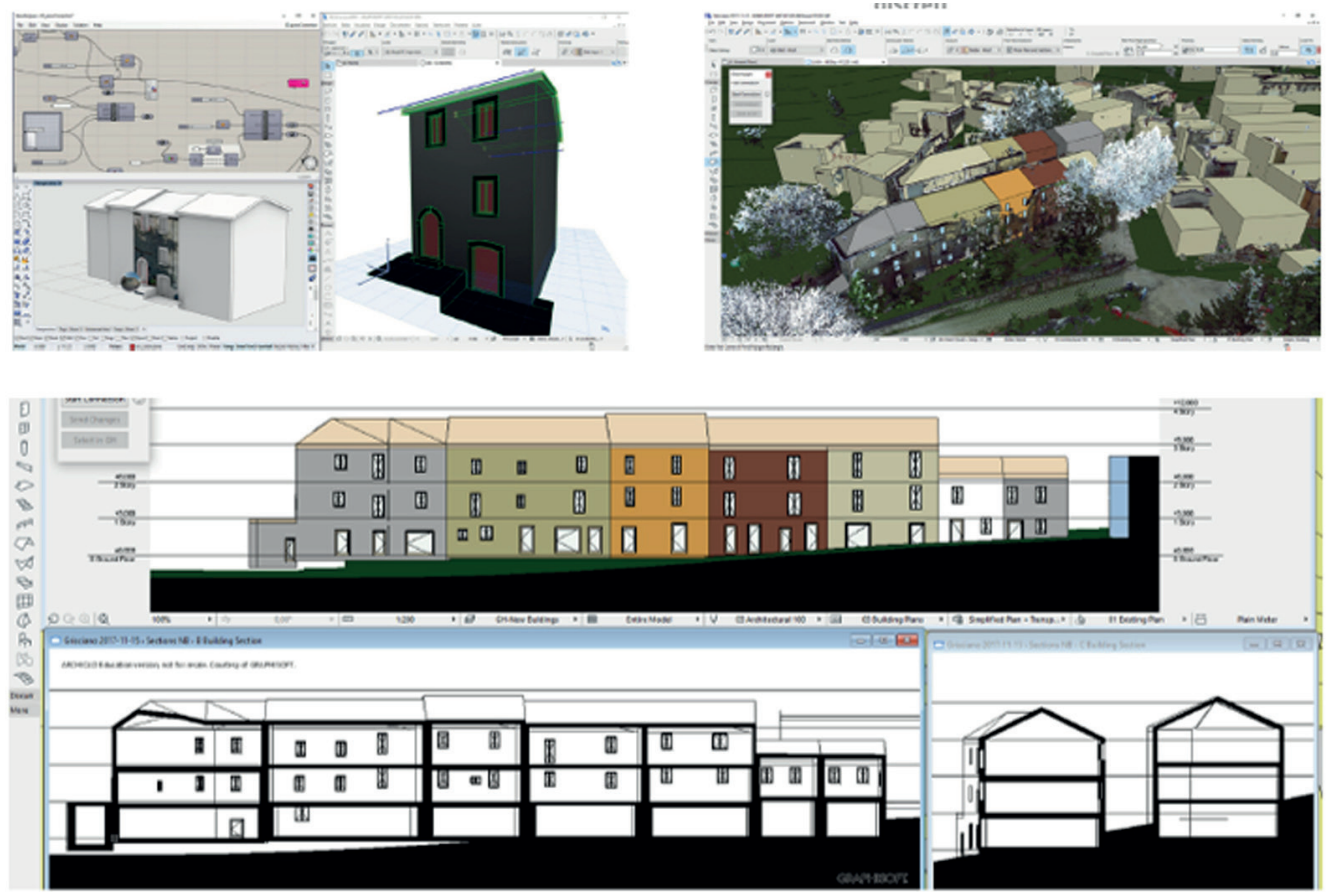

II primo passo propedeutico alla costruzione del CIM consiste nel reperimento dei geo-dati in funzione dell'area territoriale di interesse. Tali dati possono essere open-data come nel caso di OpenStreetMap oppure provenienti da database degli enti presenti sul territorio. In molti casi tali dati non sono esaustivi delle caratteristiche geometriche - tecnologiche dei tessuti urbani in analisi, pertanto è necessaria una integrazione attraverso l'implementazione delle tabelle dei contenuti associati ad ogni entità geometrica presente nei geo-dati acquisiti. Tra questi: il numero di elevazioni, l'altezza media di interpiano, la tipologia costruttiva, geometria delle coperture, tipi di materiali, etc. Per tale fine, eventuali studi pregressi che hanno mappato il territorio utilizzando schede AeDES o GNDT possono velocizzare l'operazione.

La metodologia per la costruzione del modello CIM può essere suddivisa in 3 fasi di sviluppo cui corrispondono, in accordo con la letteratura esistente, livelli di dettaglio riconducibili a standard riconosciuti (fase I e 3) o nuovi livelli di dettaglio specifici che vengono definiti e implementati in funzione degli obiettivi della ricerca (fase 2).

Fase I. Adozione dei livelli di dettaglio considerati dagli standard CityGML (fig 6) per la scala territoriale LOD 0-2;

- $\quad$ Fase 2. Definizione del LOD DMEM (Discrete Macro-Element Method) che risponde alle esigenze dei modelli analitici definiti dalla disciplina della scienza delle costruzioni per l'analisi strutturale ai fini della vulnerabilità sismica, quale ad esempio il metodo discreto ai macro-elementi [Caddemi 20।8].

- $\quad$ Fase 3. Adozione del LOD DIM (Detail Information Model) che trova riferimento in letteratura [Calvano 2019], riguarda la scala architettonica ed è assimilabile ai modelli BIM.

La fase I è relativa allo sviluppo del CIM dalla scala territoriale a quella di quartiere. II LOD 0 è riferito ad una scala territoriale/paesistica. A questo livello gli edifici vengono descritti e visualizzati tramite un'impronta a terra 2D proiettata su una superficie 3D (Digital Terrain Model) la quale rappresenta la topografia dell'area di territorio considerata. Si passa quindi alla scala della città o dell'insediamento urbano (LOD I). Le impronte degli edifici vengono estruse in relazione alle altezze presenti nei metadati associati alle entità geometriche. A questo livello si delinea il paesaggio urbano nella sua consistenza volumetrica, dati associati al modello consentono il calcolo di diversi parametri urbanistici. Il passaggio al LOD 2 (scala 
Fig. 4. Da sinistra a destra: allineamento rilievo fotogrammetrico digitale al modello BIM e analisi strutturale in PROSAP [Pelliccio 2017].

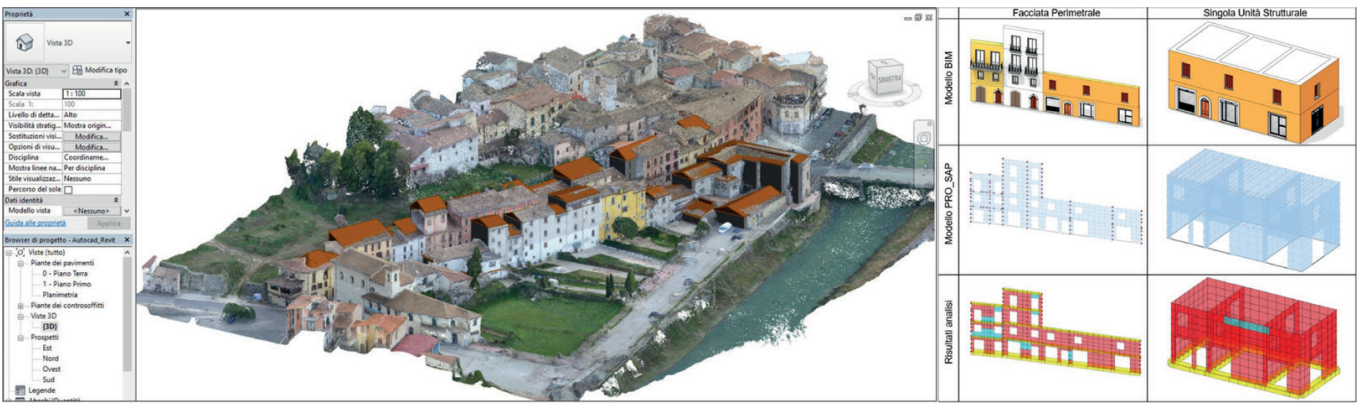

di quartiere) definisce la geometria della chiusura orizzontale di copertura e suddivide semanticamente tutte le superfici (fronte, chiusura orizzontale di base e di copertura, etc.). Nella seconda fase avviene la trasduzione delle informazioni presenti nei geo-dati consentendo di implementare le unità considerate dal LOD 2 al LOD DMEM. L'obiettivo è quello di creare dei modelli analitici compatibili alle analisi agli elementi finiti per poterne determinare la sicurezza sismica. È necessario dunque descrivere le unità sia esternamente che internamente, ciò non è sempre possibile in ambito urbano. Lo studio e la classificazione dei tipi edilizi ricorrenti presenti nel territorio considerato, unitamente ad un approccio mediante modellazione procedurale che si avvale di tale studio, consentono una prima integrazione dei dati. I modelli ottenuti, seppur non perfettamente aderenti alla realtà, descrivono le unità in maniera organica similmente a quanto si fa nella redazione degli eidotipi in fase di rilievo [Stojanovski 20 l8]. Inoltre, essi possono essere esaminati dai software di analisi strutturale permettendo una prima analisi della vulnerabilità sismica in accordo con il Livello 2 e 3 delle LLGG 20 I I. Infine, relativamente alla fase 3, le unità al LOD DMEM possiedono tutte le informazioni relative ai componenti edilizi pertanto possono evolversi in modelli BIM facilitando le operazioni di rappresentazione, gestione e migrazione dei dati. La modellazione finora raggiunta presenta spesso delle semplificazioni ed ipotesi per garantire un'analisi speditiva. Attraverso un rilievo digitale integrato (Topografico, Laser scanner, fotogrammetria terrestre e drone, GPS) e un approccio scan-to-bim è possibile aggiornare localmente tutti gli scostamenti dalla realtà dovuti agli automatismi e semplificazioni della modellazione procedurale. In sintesi, la terza fase è contraddistinta dai seguenti passaggi:

- $\quad$ DIMi (Detail Information Model ideal): consiste nella 'riscrittura rigida' del modello analitico in un modello BIM-based;
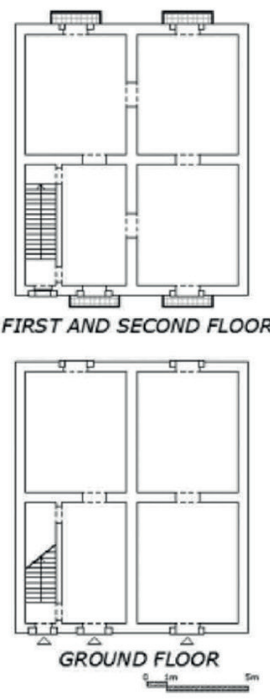
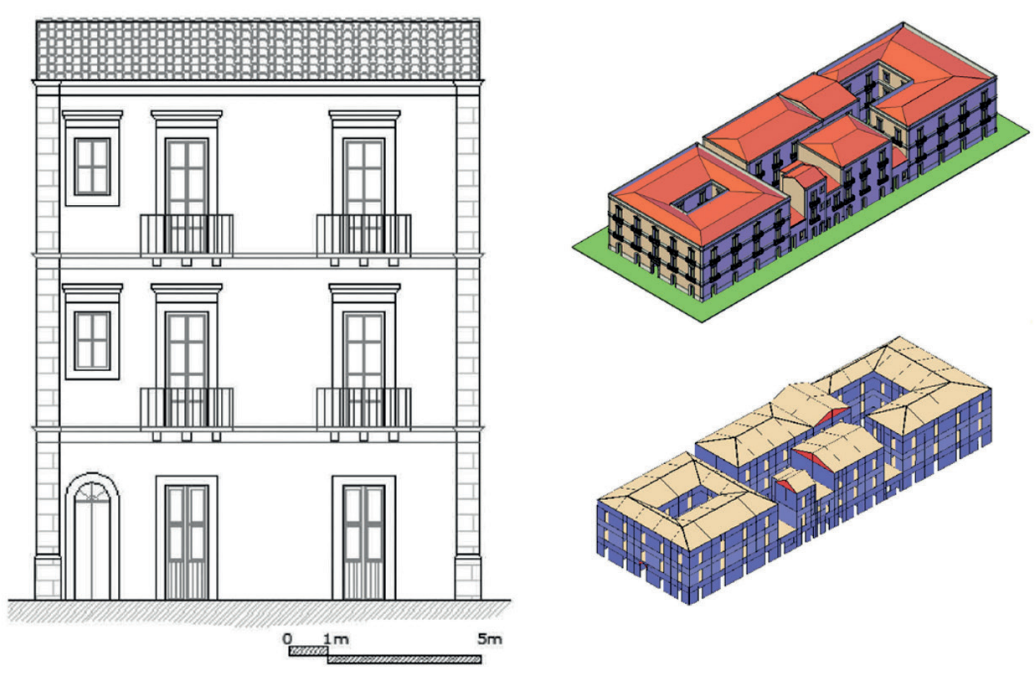
- rilievo digitale integrato (topografico, laser scanner, fotogrammetria terrestre e drone, GPS) geo-riferito al CIM;

- $\quad \operatorname{DIM}^{R}$ (Detail Information Model real): consiste nella definizione del modello as-it-is correggendo gli scostamenti del DIMi sulla base dei prodotti del rilievo strumentale.

Infine, i risultati delle analisi sulla sicurezza sismica contribuiscono all'arricchimento informativo del DIMR (fig. 7).

Al fine di confrontarsi con diversi tipi di complessità urbana, la metodologia proposta verrà implementata su due possibili scenari di applicazione su un'area territoriale vasta: centri urbani minori e centri storici.

Come campo di applicazione della ricerca è stata individuata l'area etnea della Sicilia orientale per l'elevata classe di pericolosità sismica rispetto al territorio nazionale [INGV terremoti 202 I].

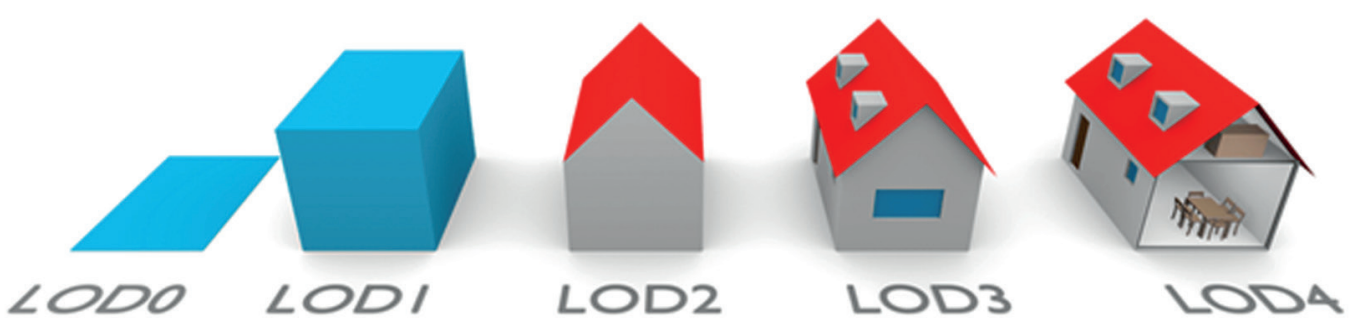

\section{Una prima applicazione dal LOD 0 al LOD 2: il caso di Fleri, Zafferana Etnea (CT)}

Tra i centri urbani minori pedemontani, la scelta è ricaduta su Fleri, frazione del comune di Zafferana Etnea in provincia di Catania, colpita nel 2018 da un evento sismico che ha danneggiato diversi edifici (diversi dei quali tuttora inagibili). Le dimensioni contenute, la presenza di varie tipologie edilizie storiche simili a quelle riscontrabili nel centro storico di Catania e l'attuale stato post-sisma la rendono un caso studio esemplificativo rispetto ai centri urbani minori. La struttura urbana è di tipo nastriforme con lotti stretti e lunghi che si susseguono lungo la via Vittorio Emanuele, direttrice di collegamento in direzione nord-sud tra i centri diViagrande e Zafferana Etnea.

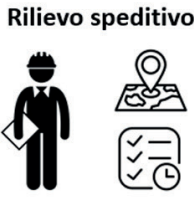

Modellazione procedurale (tipi)

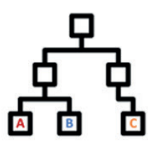

Rilievi in sito

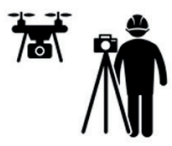

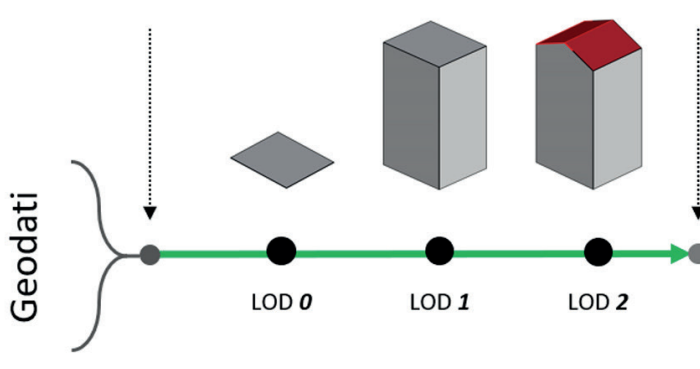

Fasi di sviluppo:

Fase 1: scala territoriale e di quartiere Fase 2: modello analisi strutturali Fase 3: scala architettonica
Fig. 7. Schema concettuale metodologia proposta.

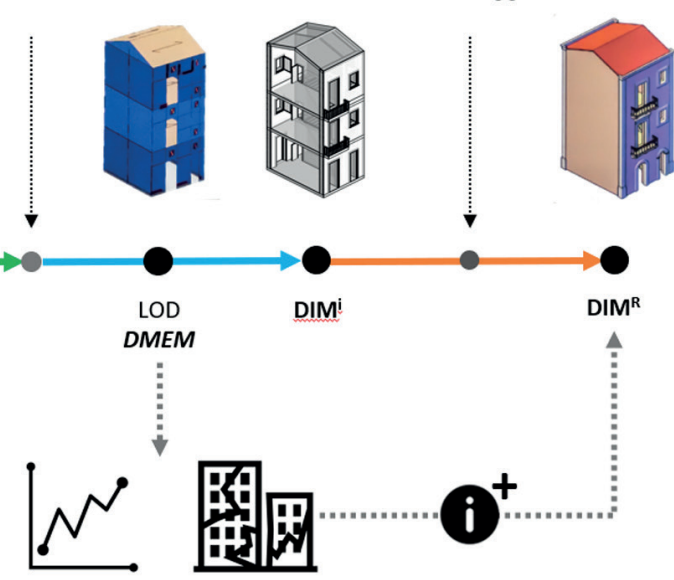

Analisi FME 
Fig. 8. Da sinistra a destra: mappa catastale I 888 della Borgata Fleri, pianta catastale 1933 2004. Fonte: Archivio fotografico del DICAR Università degli Studi di Catania.

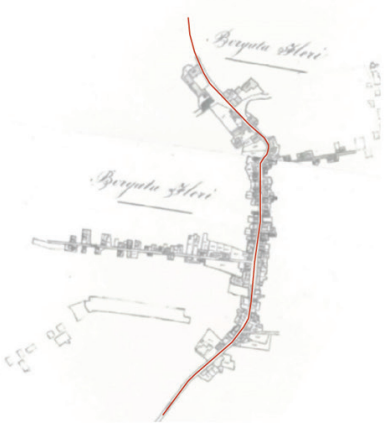

1888

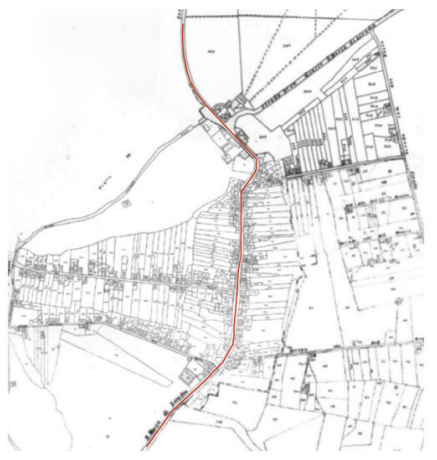

1933

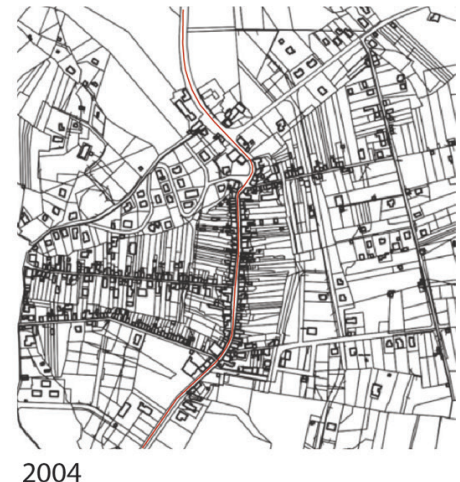

2004

Rispetto alla metodologia proposta, ci si è concentrati sul framework relativo alla modellazione informativa urbana dal LOD 0 al LOD 2.

Il primo passo nel processo di conoscenza è stato il reperimento dei geo-dati attraverso OpenStreetMap (OSM). Tali dati sono stati connessi ad un ambiente di modellazione parametrica (il VPL Grasshopper di Rhinoceros) in maniera tale da consentire l'aggiornamento automatico degli stessi nel tempo.

Contestualmente al reperimento dei geo-dati è stata condotta un'indagine storica riguardo l'evoluzione del tessuto urbano in modo tale da individuare caratteristiche e tecniche costruttive utili alle definizioni delle tipologie costruttive (fig. 8). Oltre alla redazione di eidotipi e schizzi in sito utili alla comprensione della scena urbana, sono state consultate cartografie storiche e i catastali delle unità edilizie prospicienti la via Vittorio Emanuele.

La ricognizione in situ ha consentito di integrare i geo-dati di OSM con ulteriori informazioni (ad esempio il numero di elevazioni) propedeutiche alla definizione delle geometrie. Si è pertanto proceduto alla modellazione dei LOD 0, I e 2 in ambiente Rhinoceros grazie all'utilizzo del plug-in Gismo disponibile per Grasshopper [La Russa 2020] (fig. 9).

Si è proceduto quindi con una campagna di rilievo strumentale del canyon urbano con la sperimentazione e il confronto di diverse tecniche di acquisizione (Laser scanning, fotogrammetria con camere tradizionali e immersive low cost) e la successiva georeferenziazione della nuvola di punti allinterno dell'ambiente di lavoro (fig. I0).

II rilievo metrico e la documentazione catastale (indispensabile per la comprensione della distribuzione interna) hanno costituito il supporto per l'analisi e la classificazione delle tipologie edilizie, per la ricerca di varianti ed invarianti ed evoluzioni tipologiche, propedeutica alla fase di modellazione procedurale [La Russa 202I].

Fig. 9. Modello LOD 0 (in altro a sinistra) e LOD I (in alto a destra), codice VPL per l'estrazione di metadati da OpenStreetMap (in basso a sinistra) e modello
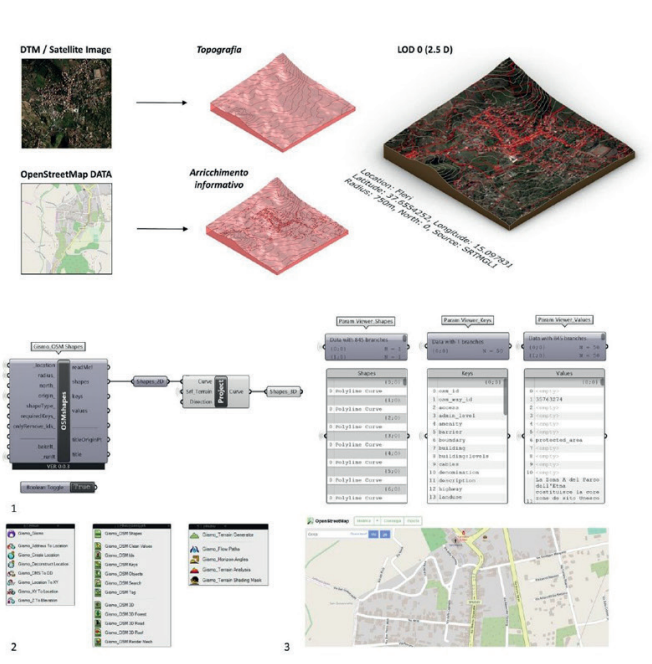


\section{Conclusioni e sviluppi futuri}

II paradigma del City Information Modelling delineato dalla proposta metodologica descritta in questa sede si propone di conciliare le metodologie consolidate del rilievo urbano a quelle più recenti riportando al centro dell'attenzione il rilevatore e la sua formazione. Sotto questo profilo, l'iterazione dei processi generata dai passaggi computazionali non si sostituisce al rilevatore ma enfatizza la sua conoscenza permettendogli in maniera sempre più integrata un passaggio dalla scala territoriale a quella urbana, fino ad arrivare a quella architettonica in cui ci si confronta con le peculiarità delle emergenze architettoniche.

Il percorso della conoscenza è di tipo deduttivo e consente alle amministrazioni, sia di grandi che di piccoli centri, di sviluppare il proprio City Information Model a partire da dati in loro possesso o disponibili nel web e implementarli per le fasi successive. Tale approccio garantisce la sostenibilità economica dell'intervento iniziale, rimandando a tempi successivi le operazioni di rilievo digitale, onerose sia in termini di costi che di energie.

La natura parametrica e responsiva del CIM consente di lavorare e integrare dati mancanti in qualsiasi punto del flusso di lavoro e a qualsiasi scala senza che ciò determini una completa ridefinizione del modello. In scenari con elevata pericolosità sismica tale caratteristica permette di aggiornare in tempi rapidi e sostenibili le informazioni relative allo stato delle unità colpite.

II City Information Modelling non è comunque da considerare una mera sommatoria di modelli BIM interrogabili ma un vero e proprio paesaggio digitale dove viene prodotta e messa a sistema nuova conoscenza dalle relazioni tra le parti della città. Tale libertà porta inevitabilmente con sé una moltitudine di sfumature relativa alla definizione del livello di geometria e di informazione del CIM stesso. Ad oggi è possibile utilizzare degli standard solo abbracciando completamente l'approccio territoriale (ex. standard CityGML) o quello architettonico-costruttivo (ex. UNI I I 337 per l'Italia). Si evidenzia quindi un'assenza a livello internazionale di standardizzazione dei livelli di dettaglio concepiti appositamente per l'interoperabilità GIS e BIM. Tale lacuna si spera sia colmata dalla norma ISO/PRF TR 23262, attualmente in fase di sviluppo, che si focalizza su questo tema.

La ricerca attualmente si sta occupando dello sviluppo del framework per la modellazione procedurale dei tipi edilizi funzionale all'analisi della vulnerabilità sismica. Quali sviluppi futuri si prevede di ridefinire i livelli di dettaglio dei modelli digitali urbani secondo il 'Level of information Need come stabilito dalla norma UNI EN ISO 19650:2019 in maniera tale da poter indicare, fase per fase, quali siano il livello di geometria ed informazione richiesto nel CIM specifico della ricerca in accordo ad una norma internazionale.

Fig. 10. Vista della nuvola di punti acquisita tramite laser scanner (a sinistra) Georeferenziazione all'interno del modello CIM realizzato in

Grasshopper (a destra).
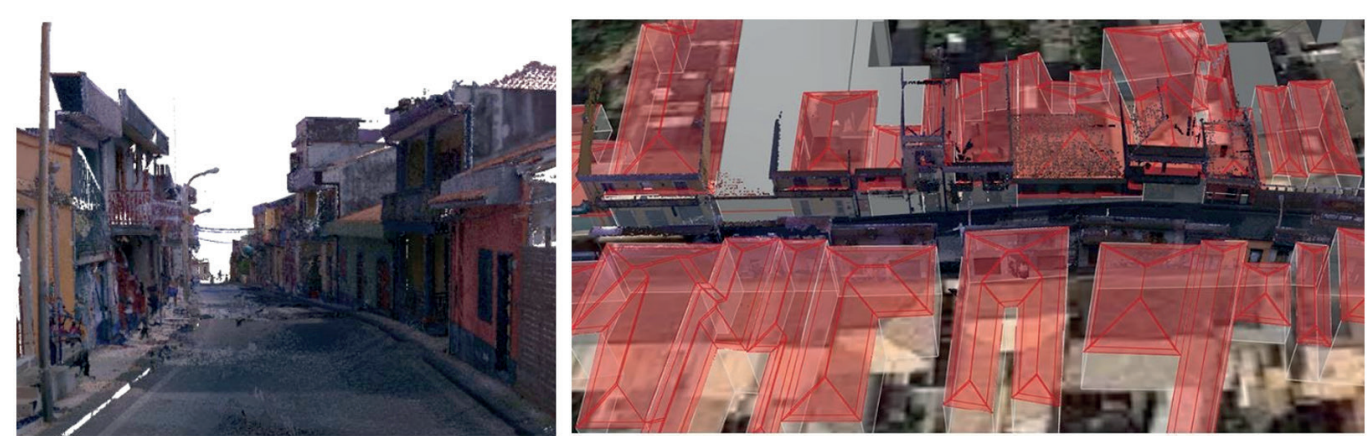

Introduzione (Cettina Santagati); Una metodologia innovativa per la modellazione degli aggregati urbani (Federico La Russa); Una prima applicazione dal LOD 0 al LOD 2: il caso di Fleri, Zafferana Etnea (Federico La Russa); Conclusioni e sviluppi futuri (Cettina Santagati e Federico La Russa). 


\section{Riferimenti bibliografici}

Baculo Giusti A. (a cura di). (1994). Napoli all'infinito/Naples in progress Napoli in assonometria ... e Napoli nel data base Una veduta della città ed una catalogazione informatizzata del patrimonio ambientale e architettonico. Napoli: Electa.

Boido C., Davico P., Spallone R. (202 I). Digital Tools Aimed to Represent Urban Survey. In Khosrow-Pour M. (Ed.). Encyclopedid of Information Science and Technology, n. 5, pp. I I 8 I- I 195. Hershey: IGl Global.

Caniggia G., Maffei G.L. (2008). Lettura dell'edilizia di base. Firenze: Alinea.

Calvano M. (2019). Disegno digitale esplicito. Rappresentazioni responsive dell'architettura e della città. Roma:Aracne.

Calvano M., Empler T., Caldarone A. (2019). L'ARIM per la prevenzione del rischio sismico. In Disegnare Idee Immagini, n. 59 pp. 70-81.

Caniggia G., Maffei G.L. (1979). Composizione architettonica e tipologia edilizia I. Lettura dell'edilizia di base. Venezia: Marsilio.

Coppo D., Boido C. (2010). Rilievo Urbano, conoscenza e rappresentazione della città consolidata. Firenze: Alinea.

Garzino G., Novello G., Bocconcino M.M. (2019). Handbook of Research on Urban and Territorial Systems and the Intangible Dimension: Survey and Representation. In Inglese C., Ippolito A. (a cura di). Conservation, Restoration, and Analysis of Architectural and Archaeological Heritage, pp. 346-385. Hershey: IGl Global.

Goodchild M. F. ( 199 I). Geographic information systems. In Progress in Human Geography, n. I 5(2), pp. 194-200.

Greco A., Lombardo G. (a cura di). (20 8). La vulnerabilità sismica degli edifici storici in aggregato. Nuove metodologie negli approcci speditivi e di modellazione strutturale. Roma: Efesto.

INGVterremoti (202I) La pericolosità sismica. https://ingvterremoti.com/la-pericolosita-sismica/ (consultato il 7 marzo 202 I).

Julin A. et al. (20 I 8). Characterizing 3D City Modeling Projects:Towards a Harmonized Interoperable System. In ISPRS International Journal of Geo-Information, n. 7(2), p. 55.

La Russa F. M., Santagati, C. (2020). From OpenData to city models: an Antifragile approach for City Information Modeling. In Dn - Building Information Modeling, Data \& Semantics, n. 7, pp. 83-95.

La Russa F.M., Genovese G., Santagati C. (202I - in corso di stampa). II City Information Modelling tra conoscenza e prevenzione del territorio: un'applicazione in scenari post-emergenziali. In 3D Modelling \& BIM Digital Twin.

Linee Guida 201 I (20 I I). Valutazione e riduzione del rischio sismico del patrimonio culturale con riferimento alle Norme Tecniche per le costruzioni. Direttiva del Presidente del Consiglio dei Ministri 02/02/20 I I.

Liu X. et al. (2017). A State-of-the-Art Review on the Integration of Building Information Modeling (BIM) and Geographic Information System (GIS). In ISPRS International Journal of Geo-Information, n. 6(2), p. 53.

LuW. et al (20/8). The Fusion of GIS and Building Information Modeling for Big Data Analytics in Managing Development Sites In Huang B. (Ed.). Comprehensive Geographic Information Systems, pp 345-359, Elsevier.

Pelliccio A., Saccucci M., Grande E. (2017). HT_BIM: Parametric modelling for the assessment of risk in historic centers. In Disegnarecon, n. 10/18, pp. I-12.

Stojanovski, T. (2018). City Information Modelling (CIM) and Urban Design - Morphological Structure, Design Elements and Programming Classes in CIM. In Computing for a better tomorrow. Proceedings of the 36th eCAADe Conference. vol. I, pp. 507-516.

Vernizzi C. (2006). Parma e la via Emilia. Città storica, città moderna e asse fondativo: rilievo e rappresentazione. Fidenza: Mattioli 1885

Xu X., et al. (2014). From building information modeling to city information modeling. In ITcon, vol. I9, pp. 292-307. <https:// www.itcon.org/2014/17> (consultato il 7 marzo 2021).

Xue F., Wu L., Lu W. (202I). Semantic enrichment of Building and City Information Models: a ten-year review. In Advanced Engineering Informatics, n. 47, pp. I0I-245.

Autori

Federico Mario La Russa, Università degli Studi di Catania, federico.larusa@phd.unict.it Cettina Santagati, Università degli Studi di Catania, cettina.santagati@unict.it

Per citare questo capitolo: La Russa Federico Mario, Santagati Cettina (202I). Rilievo Urbano e City Information Modelling per la valutazione della vulnerabilità sismica/Urban Survey and City Information Modelling for Seismic Vulnerability Assessment. In Arena A., Arena M., Mediati D. Raffa P. (a cura di). Connettere. Un disegno per annodare e tessere Linguagoi Distanze Tecnologie. Atti del $42^{\circ}$ Convegno Internazionale dei Docenti delle Discipline dello RoppresentazionelConnecting Drowing for weaving relationship Languages Distances Technologies. Proceedings of the 42th Internationd Conference of Representation Disciplines Teachers. Milano: FrancoAngeli, pp. 2385-2402. 


\title{
Urban Survey and City Information Modelling for Seismic Vulnerability Assessment
}

\author{
Federico Mario La Russa \\ Cettina Santagati
}

Abstract

The paper proposes the definition of a methodology that integrates the consolidated methods of urban survey with the current paradigm of City Information Modeling to support the assessment of seismic vulnerability at the urban scale by adopting an expeditious approach. This approach is based on the use of geodata (generally held by public administrations or available as open data) as an indirect source through which to implement the informed and responsive city model. In addition, a procedural modeling strategy based on knowledge of building types is introduced to complement the basic information and to obtain early indicative assessments. This approach guarantees the economic sustainability of the starting intervention, postponing to later times the digital survey operations required for accurate knowledge and geometric description of the building units, but costly and time-consuming.

Keywords

3D city models, City Information Modeling (CIM), urban survey, risk assessment, building typologies.

View of the CIM model of Fleri (Zafferana Etnea Sicily). In the background a section of the VPL code used for the modeling

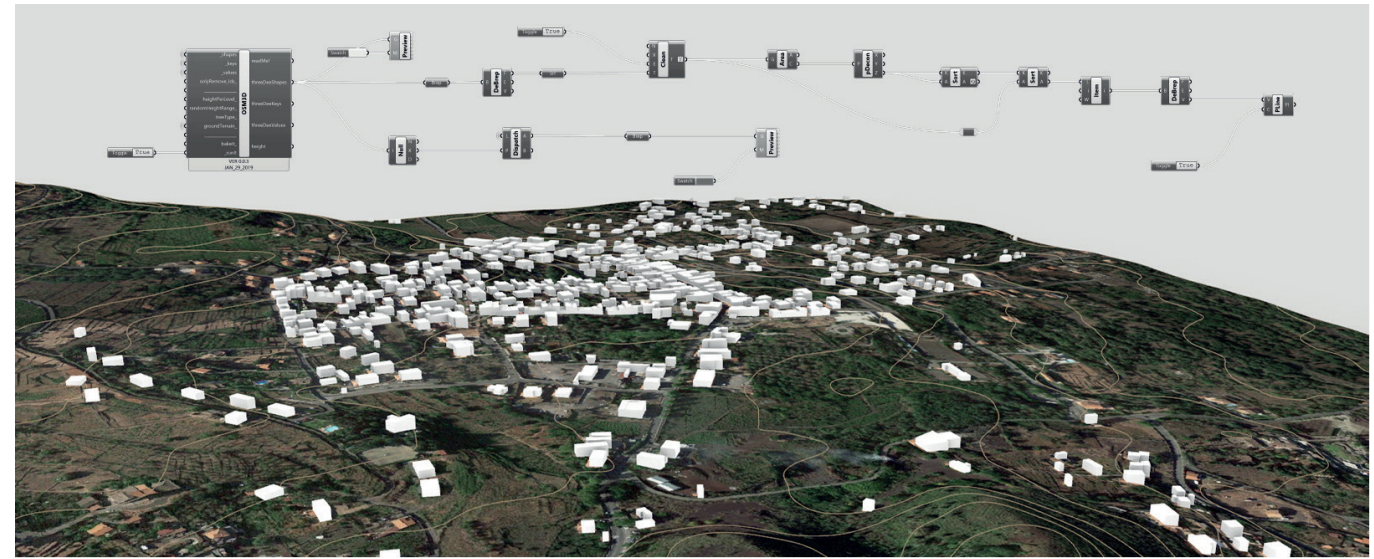




\section{Introduction}

The high seismicity of the Italian territory is undermining the integrity of our cities' built heritage. Knowing the different degrees of seismic vulnerability, and therefore the risk associated with it, makes it possible to establish priorities for mitigation actions and optimise the financial resources to be invested. The workflow indicated by the 20I I Guidelines (LLGG 20II) for seismic risk assessment and reduction describes an analysis for individual buildings. However, its extension to the scale of the city and urban aggregates requires that the survey takes into account the complexity and multidimensionality of the different aspects that characterise the city and urban structure. In fact, each single unit, besides being characterised by its specificity, is also related to the surrounding buildings. The consolidated methodologies of the Urban Survey [Baculo 1994; Vernizzi 2006; Caniggia 2008; Garzino 2019; Boido 202 I], which describe and represent "the set of values present in the investigated realities, in order to build the set of formal and structural invariants" [Coppo 20 I0, p. 12], are still very topical today (fig. I). They provide the scientific background to the experiments related to the application of the City Information Modeling paradigm for the development of informed and responsive city models for seismic vulnerability assessment.

The definition of City Information Modeling is a very controversial issue in the international debate due to the hybrid nature of BIM and GIS. Nevertheless, it is possible to identify specific characters that allow a clear distinction between a CIM and a 3D GIS or a BIM extended to the urban scale. According to F. Xue, the useful discriminant for this operation is the significance of the "I" of "Information" in CIM compared to GIS and BIM [Xue 202I]. The first developments of CIM can be identified in applications aimed at overlapping point clouds obtained through instrumental surveys (laser scanning, photogrammetry) and geo-referenced 3D models obtained in a GIS environment [Julin 20I8] (fig. 2). In these models, information was (and still is) stratified by layers within one- and two-dimensional geometries [Goodchild 199I; Lu 20I8]. Contrary to GIS, CIM also takes into account information (such as urban flow analysis, energy simulations, construction techniques, etc.) that are related to each other through cause-effect relationships (similar to what happens in BIM) and not only through topological adjacency. Still, it is possible to assume that a semantically defined 3D model within a GIS environment can be considered a specific type of CIM [Xu 20 I4; Liu 20 I7].

Fig. I. Survey of the neighbourhood of Via Pietro Micca (Turin) and analysis of the built to UN1 7310/74 [Coppo $310 / 74$ [Coppo 2010]
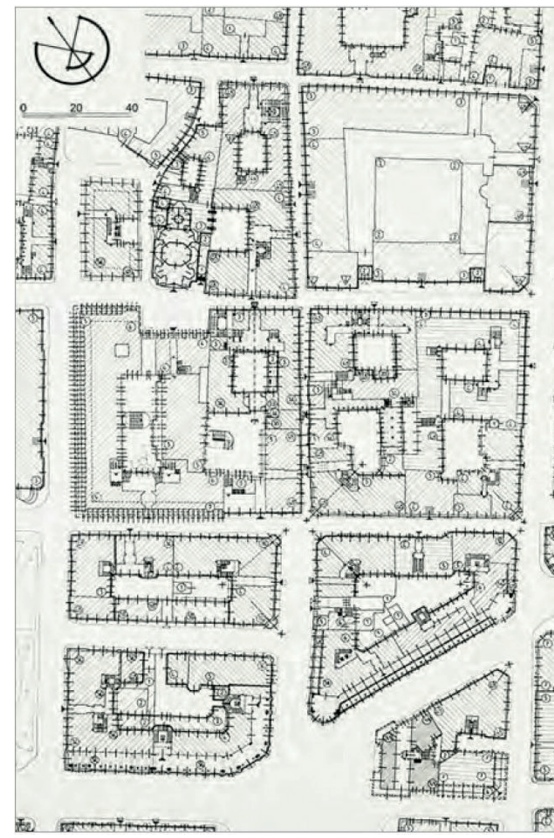
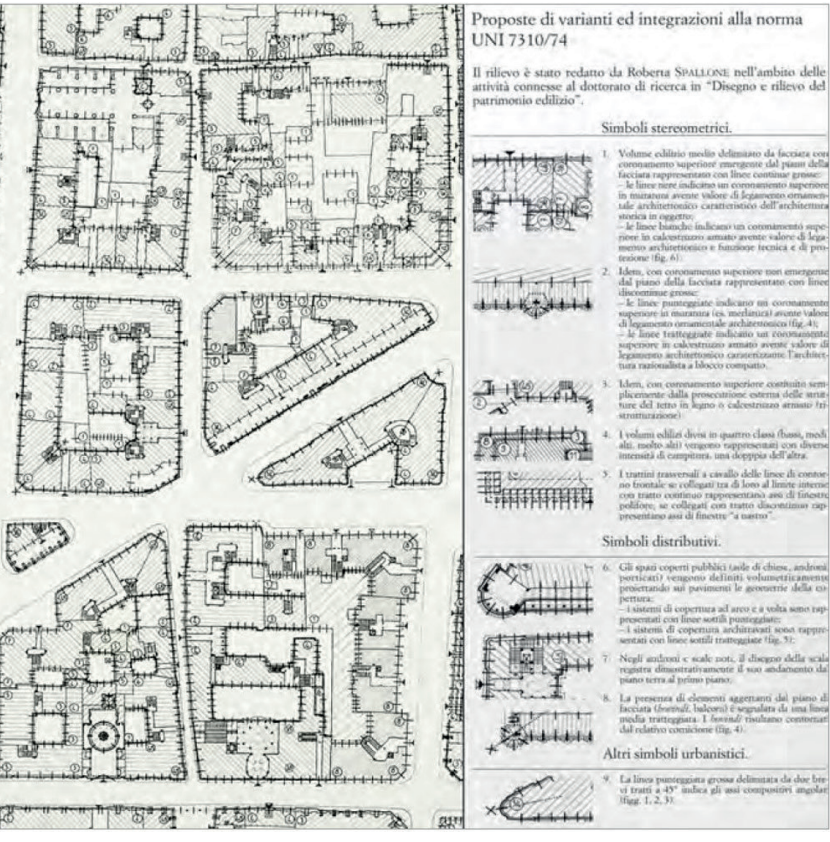
Fig. 2. View of the threedimensional information system Helsinki 3D+. It is possible to consult the system both as the system both as a CIM (created from and laser scanner point clouds) and as a 'Reality clouds) and as a 'Reality Mesh Model' (polygonal photogrammetric mode obtained from aerial photographs of the entire city). Source: Helsink 3D+ Information Model. $<$ https://kartta.hel.fi/3d/> (accessed 2021, March 10)

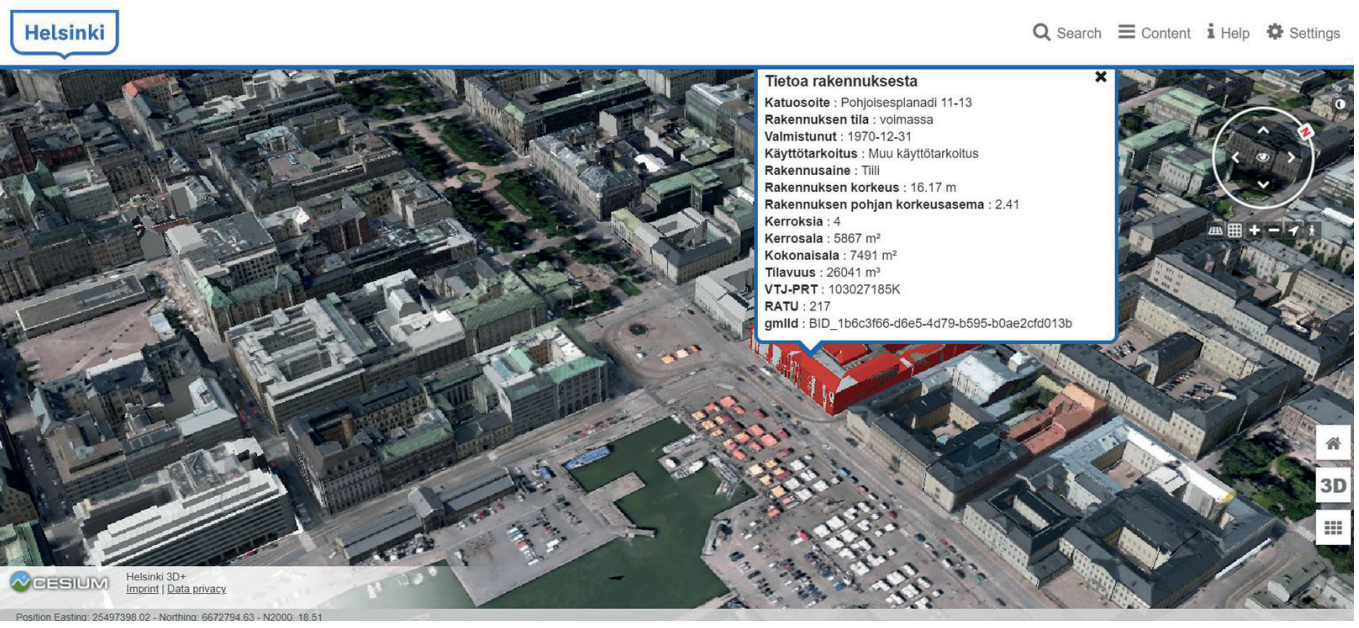

While BIM enables the management of all the information at the architectural scale functional to the design, management and conservation of a given architecture, in the case of CIM there is a relationship between the individual architectural unit and the information linked to the three-dimensional urban context [Xu 20I4].

The aim of the research is to develop a methodology that integrates established urban survey methods for the development of a CIM to support seismic vulnerability assessment using an expeditious approach.

In this direction, two further objectives are identified: the definition of a workflow for deterministic seismic vulnerability analysis; the development of a procedural modelling method based on the knowledge of building types.

\section{A novel methodology for modelling urban aggregates}

A number of research groups at the national level have been dealing with the topic of city survey and representation through 2D/3D information systems aimed at seismic risk prevention and management. For instances, the ARIM (Assessment Reconstruction Information Modeling) methodology developed on the occasion of the Amatrice earthquake [Empler 20 I9] (fig. 3), the HT_BIM (Historical Town Building Information Modeling) for risk analysis in historical centres [Pellicio et al. 2017] (fig. 4), the project "The seismic vulnerability of aggregate historical buildings. New methodologies and expeditious and structural modelling approaches" [Greco, Lombardo 2018] provided the methodological background for the ongoing research (fig. 5).

The proposed methodology aims to advance the state of the art through a stronger integration between the two disciplines most involved: urban surveying and modelling on the one hand and building science on the other.

The research foresees the use of direct data (on-site surveys) and derived data (Geo-Data available on the territory) for the development of a City Information Model to support seismic assessment on an urban scale. The methodology consists of a main framework which, starting from geo-data integrated with the urban survey, the study of building types and procedural modelling, defines a CIM which contains all the building units of the territorial area considered. Even if the parametric approach is well suited to the study of typologies and responds to the need to create analytical models useful for the analysis of the seismic vulnerability of building units in urban aggregates, the presence of monumental buildings would require specific modelling techniques that take into account their peculiarities and uniqueness.

CIM modelling is developed in a semi-automatic way, exploiting the potential of visual programming languages (VPL) which allow, through specific digital modelling environments, parametric and responsive geometry management. 
Fig. 3. Modelling environments of the ARIM procedure: from the parametric model to the BIM model [Calvano 2019].
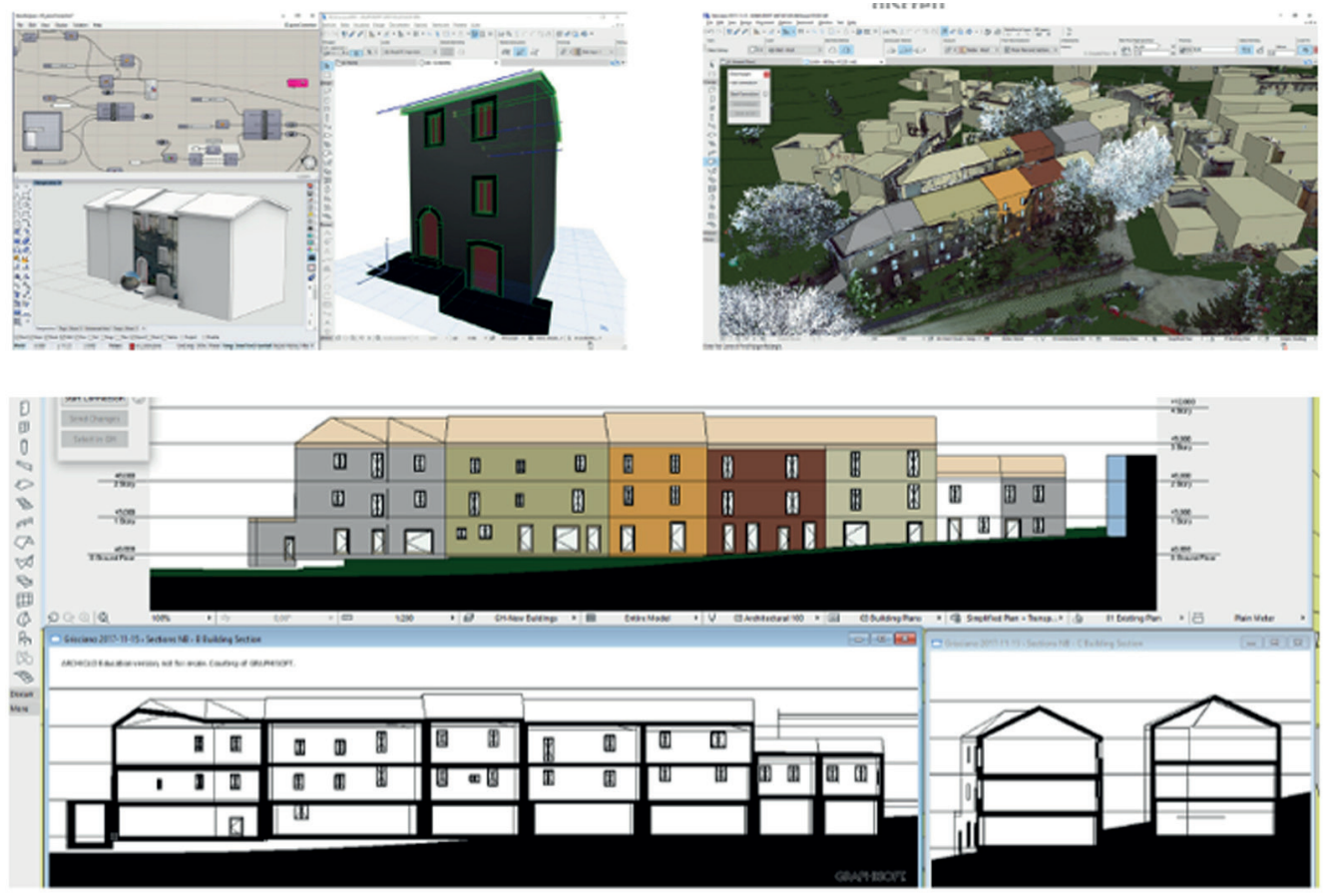

The first step in setting up the CIM is to collect geo-data in relation to the territorial area of interest. These data may be open data, as in the case of OpenStreetMap, or they may come from the databases of the local institutions.

In many cases, these data are not exhaustive of the geometric-technological characteristics of the urban areas under analysis, therefore it is necessary to integrate them by implementing the tables of information associated with each geometric entity in the collected geo-data. Examples of this information are: number of elevations, average height of storeys, building type, roof geometry, types of materials, etc. For this purpose, any previous studies that mapped the territory using AeDES or GNDT sheets can speed up the process.

The methodology for designing the CIM model can be subdivided into three development phases which correspond, in accordance with the existing literature, to levels of detail that can be referred to recognised standards (phases I and 3) or new specific levels of detail that are defined and implemented according to the research objectives (phase 2).

- $\quad$ Phase I. Adoption of the levels of detail considered by the CityGML standards (fig. 6) for the LOD 0-2 territorial and landscape scale;

- $\quad$ Phase 2. Definition of the LOD DMEM (Discrete Macro-Element Method) that fulfils the requirements of analytical models for structural analysis in relation to seismic vulnerability purposes, such as the discrete macro-element method [Caddemi 20 I8];

Phase 3. Adoption of the LOD DIM (Detail Information Model) which is referenced in the literature [Calvano 2019], it regards the architectural scale and is assimilated to BIM models.

Phase I relates to the development of the CIM from the territorial to the neighbourhood scale. LOD 0 concerns the territorial/landscape scale. At this level, buildings are described and visualised by means of a 2D footprint projected onto a 3D surface (Digital Terrain Model) which represents the topography of the considered area. Then, we move on to the scale of the city or urban settlement (LOD I). The building footprints are extruded in relation to the heights listed in the metadata associated with the geometric entities. At this level the urban landscape is delineated in its volumetric consistency and metadata associated with the 
Fig. 4. From left to right: alignment of digital photogrammetric survey to BIM model and structural analysis in PROSAP [Pelliccio 2017 ]

Fig. 5. On the left: building type 'bicellular in-line house', on the right: urban aggregate type and corresponding analytical analysis [Greco et a. analysis [Greco et a. 2018]

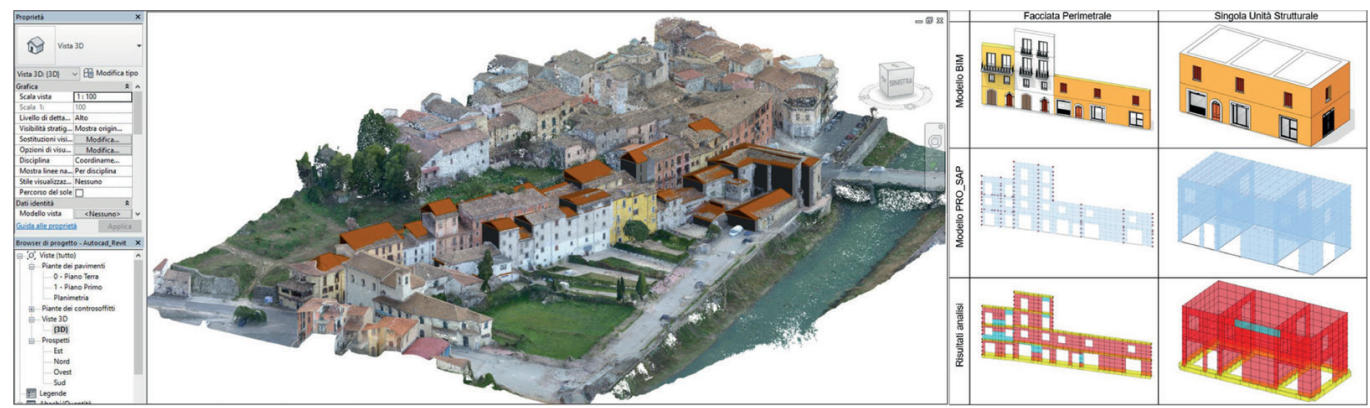

model allows the calculation of various urban planning parameters. The transition to LOD 2 (neighbourhood scale) defines the geometry of the roofs and semantically subdivides all surfaces (front, floors, roof, etc.).

In the second phase the metadata transduction takes place, allowing the implementation of the considered units from LOD 2 to LOD DMEM. The objective is to create analytical models compatible with finite element analysis in order to determine their seismic safety. It is therefore necessary to describe the buildings both externally and internally, which is not always possible in urban areas. The study and classification of recurrent building types present in the considered territory allows, through procedural modelling, the integration of data. The models obtained, although not perfectly adhering to reality, describe the buildings similarly to the preliminary study urban sketches [Stojanovski 2018]. Moreover, they can be examined by structural analysis software thus providing a first assessment of seismic vulnerability in accordance with Level 2 and 3 of the national guidelines (LLGG 20II).

Finally, with regard to phase 3 , the buildings at the LOD DMEM contain all the information about the building components. Hence, they can evolve into BIM models, facilitating the operations of representation, management and data migration. The modelling in this phase often presents simplifications and assumptions to ensure an expeditious analysis. It is however possible to locally update all deviations from reality due to the automatisms and simplifications of procedural modelling through an integrated digital survey (topography, laser scanner, ground and drone photogrammetry, GPS) and a scan-to-bim approach. In summary, the third phase is characterised by the following steps:

- $\quad$ DIMi (Detail Information Model ideal): consists of the conversion without any modification of the analytical model into a BIM-based model;
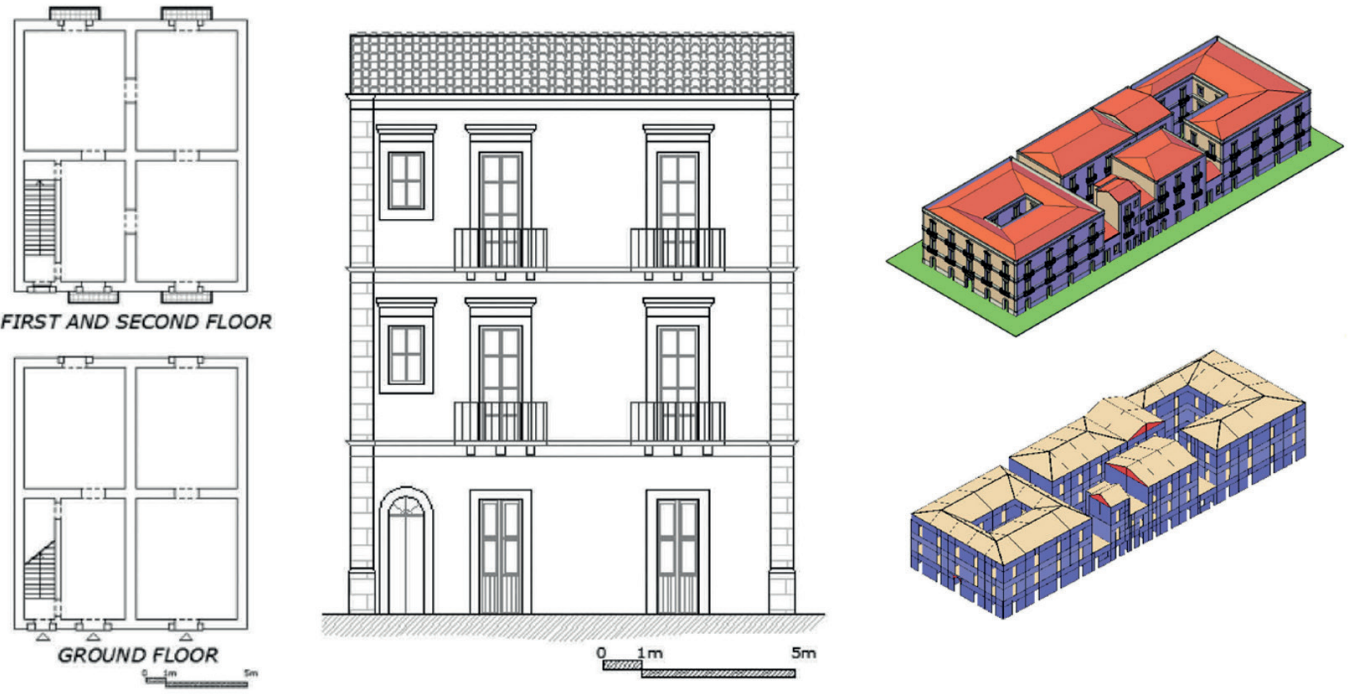
- $\quad$ integrated digital survey (topographic, laser scanner, ground and drone photogrammetry, GPS) geo-referenced to CIM;

- $\quad \operatorname{DIM}^{\mathrm{R}}$ (Detail Information Model real): consists in defining the as-it-is model by correcting DIMi deviations based on the outputs of the instrumental survey.

Finally, the results of the seismic safety analyses contribute to the information enrichment of the DIMR (fig. 7).

To confront different types of urban complexity, the proposed methodology will be implemented on two possible scenarios of application on a wide territorial area: smaller urban centres and historical centres. The Etnean area of eastern Sicily has been identified as a region of experimentation due to its high seismic hazard class compared to the national territory [INGVterremoti 202I].

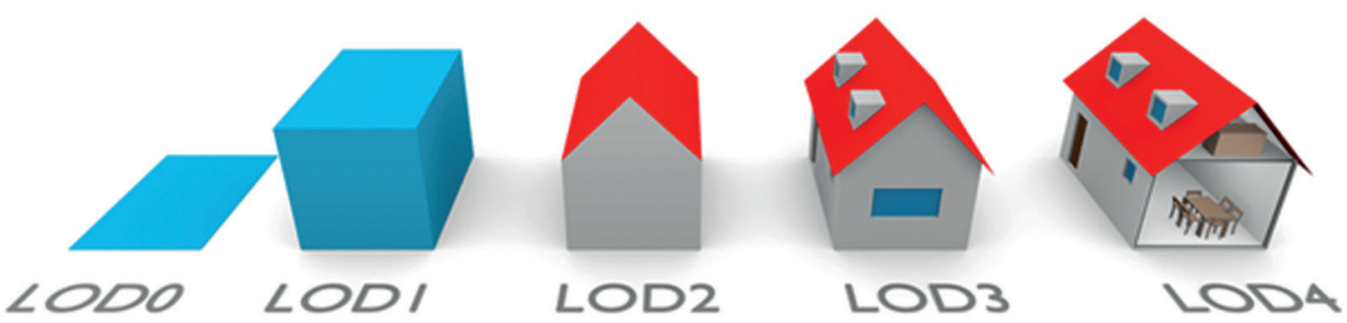

\section{A first implementation from LOD 0 to LOD 2: the case of Fleri, Zafferana Etnea (CT)}

Among the minor urban centres, the choice fell on Fleri, a village located inside the municipality of Zafferana Etnea in the province of Catania, which was shocked in 2018 by a seismic event that damaged several buildings (some of which are still uninhabitable). The characteristics that make it an appropriate case study are: its small size, the presence of various historical building types similar to those found in the historical centre of Catania and its current post-earthquake status. The urban structure is made up of narrow and long lots in sequence along Via Vittorio Emanuele, the north-south axis linking the centres of Viagrande

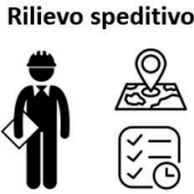

Modellazione procedurale (tipi)

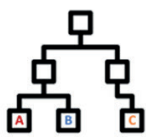

Rilievi in sito

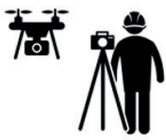

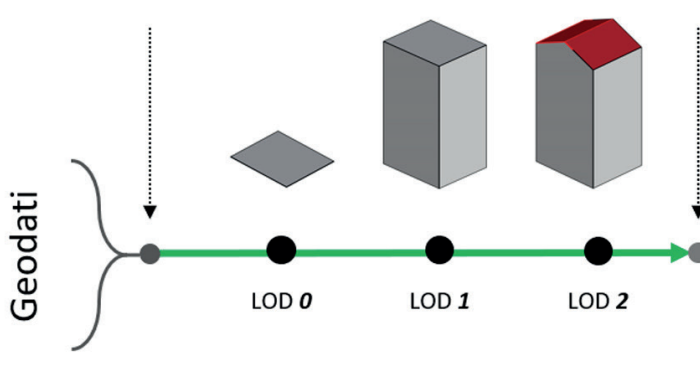

Fasi di sviluppo:

Fase 1: scala territoriale e di quartiere Fase 2: modello analisi strutturali Fase 3: scala architettonica

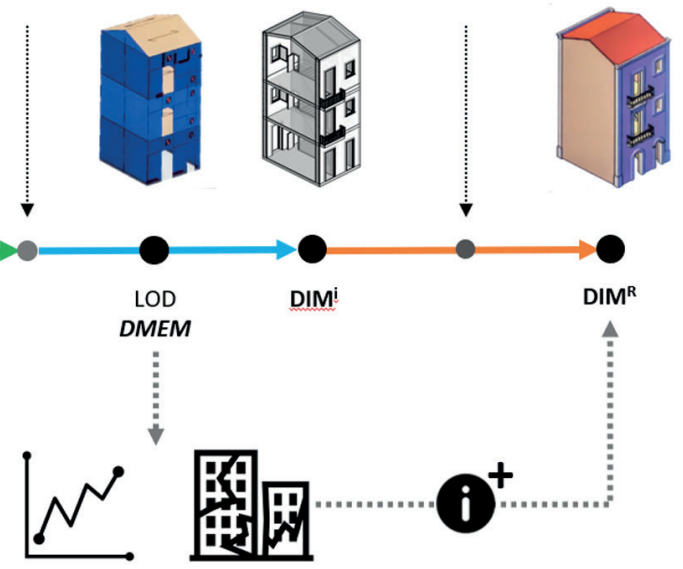

Analisi FME 
Fig. 8. From left to right: 1888 cadastral map of Borgata Fleri, 1933 and 2004 cadastral map of Pleri. Source: DICAR hotographic Archive, Università degli Studi di Catania.

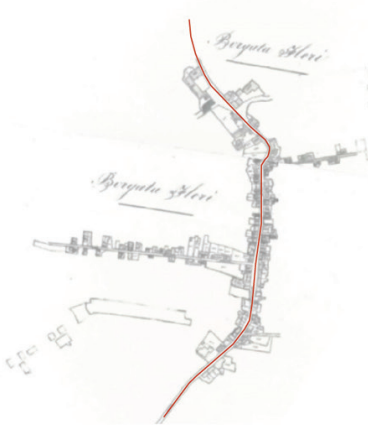

1888

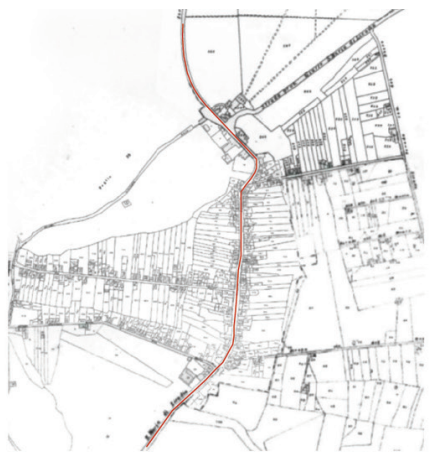

1933

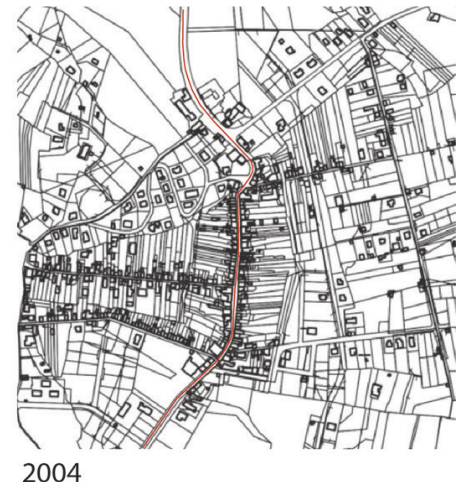

2004

and Zafferana Etnea. With regards to the proposed methodology, we focused on the framework related to urban information modelling from LOD 0 to LOD 2.

The first step in the knowledge process was the retrieval of geo-data through OpenStreetMap (OSM). Afterwards, we connected this data to a parametric modelling environment (Grasshopper) to automatically update the data over time.

Simultaneously with geo-data retrieval, we conducted a historical research regarding the evolution of the urban structure in order to identify characteristics and construction techniques useful for the definition of the building types (fig. 8). The production of eidotypes and urban sketches on site were useful for the understanding of the urban scene. In addition, we consulted historical maps and cadastral records of the urban canyon under investigation. The on-site survey made it possible to integrate the OSM geo-data with additional information (e.g. the number of elevations) required for the design of the geometries. Thus, LOD 0,1 and 2 were modelled in Rhinoceros using the Gismo plug-in available for Grasshopper [La Russa 2020] (fig. 9).

Then, we proceeded with an instrumental survey campaign of the urban canyon with the experimentation and comparison of different acquisition techniques (laser scanning, photogrammetry with traditional and low cost immersive cameras) and the subsequent geo-referencing of the point cloud within the work environment (fig. I0).

The metric survey and the cadastral documentation (indispensable for understanding the interior distribution) constituted the support for the analysis and classification of the building types. This allowed the identification of variants, invariants and typological evolutions in order to support the procedural modelling phase [La Russa 202I].

Fig. 9. Model LOD 0 (top right) VPL (top right), VPL code for metadata extraction from OpenstreetMap (bottom left) and model LOD 2 (bottom right).
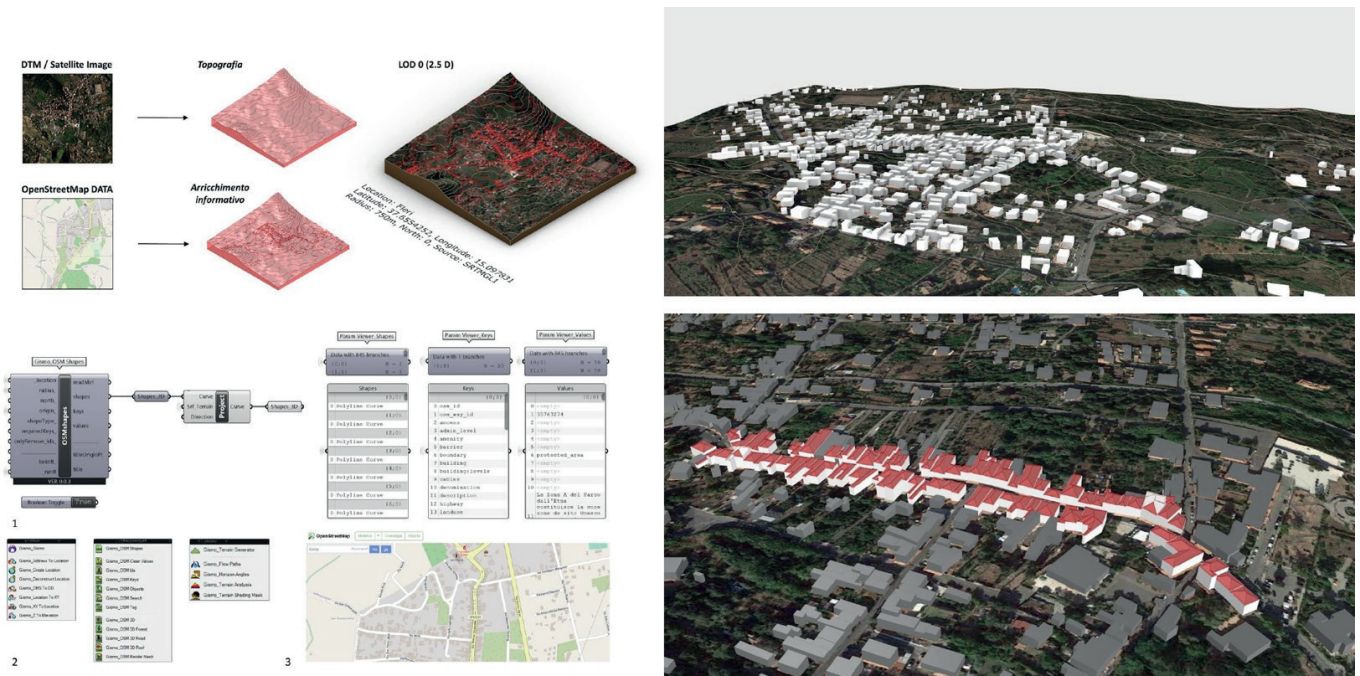


\section{Conclusions and future developments}

The City Information Modeling paradigm outlined by the methodological proposal here described, proposes to reconcile the consolidated methodologies of urban survey with the most recent ones, bringing the surveyor and his training back to the centre of attention. Under this profile, the iteration of the processes generated by the computational passages does not replace the surveyor but emphasizes his knowledge allowing him to manage the passage from the territorial scale to the urban one. In this way, he is able to approach the architectural scale dealing with the peculiarities of the architectural cultural heritage.

The knowledge process is deductive and allows municipalities, both large and small, to develop their own City Information Model from data in their possession or available on the web. This approach ensures the economic sustainability of the initial intervention, postponing the expensive and energy-intensive digital survey operations to a later phase.

The parametric and responsive nature of CIM allows for missing data to be processed and integrated at any point in the workflow and at any scale without requiring a complete redefinition of the model. In high seismic hazard scenarios, this feature allows for rapid and sustainable updating of information regarding the status of damaged buildings.

However, City Information Modeling is not to be considered as a mere summation of 'queryable' BIM models but as a real digital landscape where new knowledge is produced and processed from the relationships between the parts of the city. This freedom inevitably brings with it complexity concerning the definition of the level of geometry and information of the CIM itself. Nowadays it is only possible to use standards that fully embrace the geographical approach (e.g. CityGML standard) or the architectural-constructive approach (e.g. UNI I I 337 for Italy). Consequently, there is a gap at international level in the standardisation of detail levels specifically designed for GIS and BIM interoperability. This gap will hopefully be filled by the ISO/PRFTR 23262 standard, currently under development, which focuses on this issue.

The research team is currently developing the framework for procedural modelling of building types for seismic vulnerability analysis. As future developments it is planned to redefine the levels of detail of the urban digital models according to the 'Level of information Need' as established by the UNI EN ISO 19650:2019 standard so that it is possible to indicate, phase by phase, which levels of geometry and information are required in the specific CIM of the study according to an international standard.

Fig. 10. View of the point cloud obtained through laser scanning (left). Georeferencing within the CIM model created in Grasshopper (right).
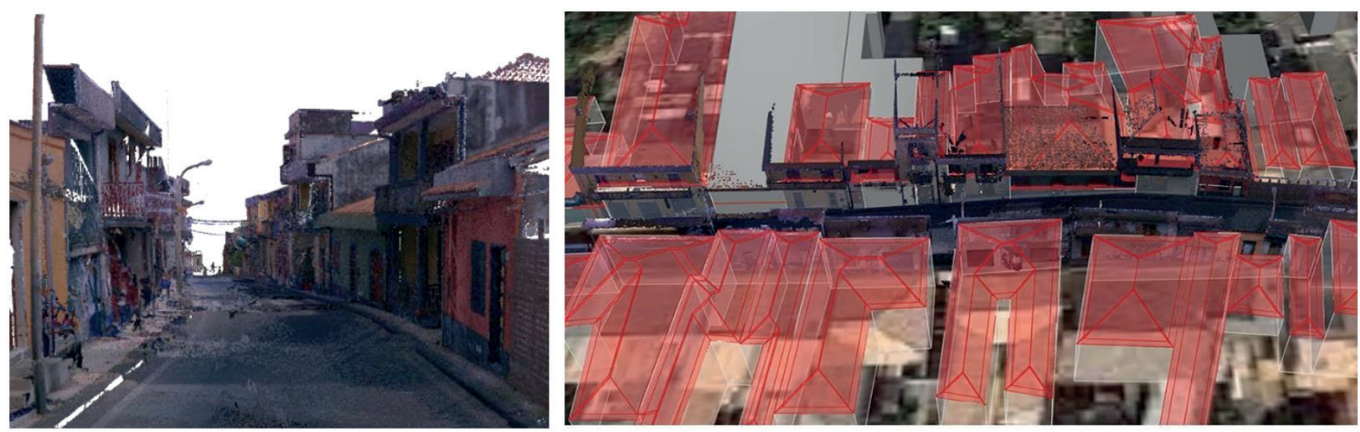

Introduction (Cettina Santagati); A novel methodology for modelling urban aggregates (Federico M. La Russa); A first implementation from LOD 0 to LOD 2: the case of Fleri, Zafferana Etnea (Federico M. La Russa); Conclusions and future developments (Cettina Santagati and Federico M. La Russa). 


\section{References}

Baculo Giusti A. (a cura di). (1994). Napoli all'infinito/Naples in progress Napoli in assonometria ... e Napoli nel data base Una veduta della città ed una catalogazione informatizzata del patrimonio ambientale e architettonico. Napoli: Electa.

Boido C., Davico P., Spallone R. (2021). Digital Tools Aimed to Represent Urban Survey. In Khosrow-Pour M. (Ed.). Encyclopedia of Information Science and Technology, n. 5, pp. I I 8 I- I 195. Hershey: IGl Global.

Caniggia G., Maffei G.L. (2008). Lettura dell'edilizia di base. Firenze: Alinea.

Calvano M. (2019). Disegno digitale esplicito. Rappresentazioni responsive dell'architettura e della città. Roma: Aracne.

Calvano M., Empler T., Caldarone A. (2019). L'ARIM per la prevenzione del rischio sismico. In Disegnare Idee Immagini, n. 59 , pp. 70-81.

Caniggia G., Maffei G.L. (1979). Composizione architettonica e tipologia edilizia I. Lettura dell'edilizia di base. Venezia: Marsilio.

Coppo D., Boido C. (20।0). Rilievo Urbano, conoscenza e rappresentazione della città consolidata. Firenze: Alinea.

Garzino G., Novello G., Bocconcino M.M. (2019). Handbook of Research on Urban and Territorial Systems and the Intangible Dimension: Survey and Representation. In Inglese C., Ippolito A. (Eds.). Conservation, Restoration, and Analysis of Architectural and Archaeological Heritage, pp. 346-385. Hershey: IGI Global.

Goodchild M. F. (199I). Geographic information systems. In Progress in Human Geography, n. I 5(2), pp. 194-200.

Greco A., Lombardo G. (a cura di). (20 I 8). La vulnerabilità sismica degli edifici storici in aggregato. Nuove metodologie negli approcci speditivi e di modellazione strutturale. Roma: Efesto.

INGVterremoti (202I) La pericolosità sismica. <https://ingvterremoti.com/la-pericolosita-sismica/> (accessed 202I, March 7).

Julin A. et al. (20I8). Characterizing 3D City Modeling Projects:Towards a Harmonized Interoperable System. In ISPRS International Journal of Geo-Information, n. 7(2), p.55.

La Russa F.M., Santagati C. (2020). From OpenData to city models: an Antifragile approach for City Information Modeling. In Dn - Building Information Modeling, Data \& Semantics, n. 7, pp. 83-95.

La Russa F. M., Genovese G., Santagati C. (202I - in corso di stampa). II City Information Modelling tra conoscenza e prevenzione del territorio: un'applicazione in scenari post-emergenziali. In 3D Modelling \& BIM Digital Twin.

Linee Guida 201 I (20 I I). Valutazione e riduzione del rischio sismico del patrimonio culturale con riferimento alle Norme Tecniche per le costruzioni. Direttiva del Presidente del Consiglio dei Ministri 02/02/20 I I.

Liu X. et al. (2017). A State-of-the-Art Review on the Integration of Building Information Modeling (BIM) and Geographic Information System (GIS). In ISPRS International Journal of Geo-Information, n. 6(2), p. 53.

LuW. et al (2018). The Fusion of GIS and Building Information Modeling for Big Data Analytics in Managing Development Sites. In Huang B. (Ed.). Comprehensive Geographic Information Systems, pp 345-359, Elsevier.

Pelliccio A., Saccucci M., Grande E. (2017). HT_BIM: Parametric modelling for the assessment of risk in historic centers. In Disegnarecon, n. 10/18, pp. I- 12.

Stojanovski, T. (2018). City Information Modelling (CIM) and Urban Design - Morphological Structure, Design Elements and Programming Classes in CIM. In Computing for a better tomorrow. Proceedings of the 36th eCAADe Conference. vol. I, pp. 507-516.

Vernizzi C. (2006). Parma e la via Emilia. Città storica, città moderna e asse fondativo: rilievo e rappresentazione. Fidenza: Mattioli 1885

Xu X., et al. (20I4). From building information modeling to city information modeling. In ITcon, vol. 19, pp. 292-307. <https:// www.itcon.org/2014/17> (accessed 2021, March 7).

Xue F., Wu L., Lu W. (202I). Semantic enrichment of Building and City Information Models: a ten-year review. In Advanced Engineering Informatics, n. 47, pp. I0I-245.

\footnotetext{
Authors

Federico Mario La Russa, Università degli Studi di Catania, federico.larusa@phd.unict.it Cettina Santagati, Università degli Studi di Catania, cettina.santagati@unict.it
}

To cite this chapter. La Russa Federico Mario, Santagati Cettina (2021). Rilievo Urbano e City Information Modelling per la valutazione della vulnerabilità sismica/Urban Survey and City Information Modelling for Seismic Vulnerability Assessment. In Arena A. Arena M. Mediati D. Raffa P. (a cura di). Connettere Un disegno per annodare e tessere Linguagoi Distanze Tecnologie. Atti del $42^{\circ}$ Convegno Internazionale dei Docenti delle Discipline della Rappresentazione/Connecting. Drawing for weaving relationship. Languages Distances Technologies. Proceedings of the 42 th International Conference of Representation Disciplines Teachers. Milano: FrancoAngeli, pp. 2385-2402. 